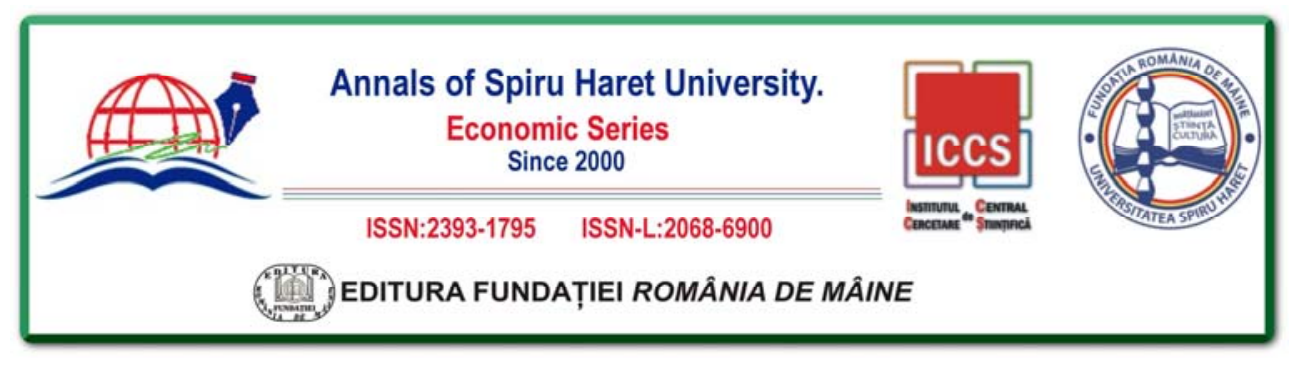

Issue $2 / 2018$

\title{
REPUTATION AND TRUST IN SHARING ECONOMY PLATFORMS: THE CASE OF TRAITY
}

\author{
Josep MARTÍNEZ-POLO ${ }^{1}$, Jesús MARTÍNEZ-SÁNCHEZ ${ }^{2}$, \\ ${ }^{1}$ Department of communication Sciences, UCAM Universidad Católica \\ San Antonio, Murcia, Spain, Email: jmmartinez@ucam.edu \\ ${ }^{2}$ Department of communication Sciences, UCAM Universidad Católica \\ San Antonio, Murcia, Spain, Email: jmsanchez@ucam.edu
}

How to cite: MARTINEZ-POLO, J., MARTINEZ-SANCHEZ, J. (2018). "Reputation and Trust in Sharing Economy Platforms: The Case of Traity." Annals of Spiru Haret University. Economic Series, 18(2), 143-158. doi: https://doi.org/10.26458/1827

\begin{abstract}
The concept of reputation is assiduously used in various fields such as communication, public relations, advertising, marketing and management. The convergence between the rise of new technologies linked to corporate communication has favoured the birth of what has been called online reputation. Thus, unprecedented behaviours have been generated that are establishing new social forms and even some authors speak of a new economy of reputation where society would be highly connected through networks and organizations that would operate in an ecosystem of permanent influence from the interest groups. With this premise, Traity arises the project that we analyzed in our research and that raises a reputational score that takes advantage of the fingerprint information to reproduce online trust as we understand it in the physical world, but without trying to reduce its people into a percentage, a number or some stars.
\end{abstract}

Keywords: reputation; collaborative consumption; sharing economy; online reputation; trust; Traity.

JEL Classification: $\mathrm{D}_{16}$ 


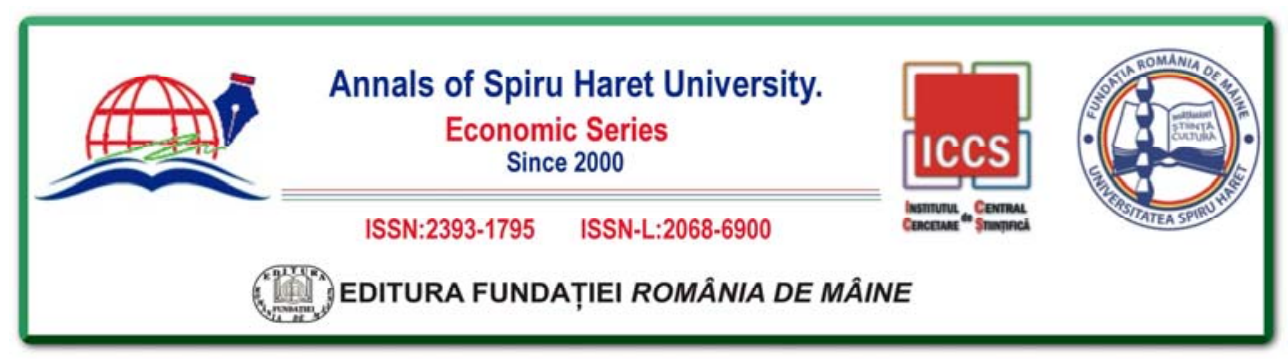

Issue 2/2018

\section{Introduction}

\subsection{Background to the study}

The concept of reputation is assiduously used in various fields such as communication, public relations, advertising, marketing and management [Capriotti, 2009]. Within the sphere of communication, "the online reputation should be understood as a part of the corporate reputation, which complements it and takes part in the global” [Itoiz, 2015]. Thus, for instance, the reputation of a company will always and above all depend on its essence, on the quality of its work and on the products and services that provides and not just on its marketing or other information reported by the media [Pizzolante, 2002].

\subsection{Statement of the problem}

Extensive research has revealed the importance and the benefit of having a good reputation at personal and organizational levels. The reputation of each person contributes to predict certain behaviours by reducing the ambiguity and uncertainty and generating reasonable expectations that nothing should be done in a contradictory manner below the expectations [Jácome López, 2015]. For that reason, it is interesting to analyze the motion of Traity to develop an online reputation system based in the digital fingerprint creating a reputational standard based in a scale of personal reliability to which information available online and verified offline is added so that the user can use it as an active to access to opportunities that are traditionally measured depending on the risk, such as digital transactions between people.

\subsection{Objective of the study}

The main objective of this study is to go deeper into the knowledge and study of a digital project such as Traity in a point in time in which we talk about the reputation and trust economy as a new currency (specially in the context of the socalled sharing economy).

Among the objectives set, we highlight:

1) to understand the online reputation phenomenon and to focus the theoretical discussion of the concept on the academic level;

2) to analyze the motion of Traity. 


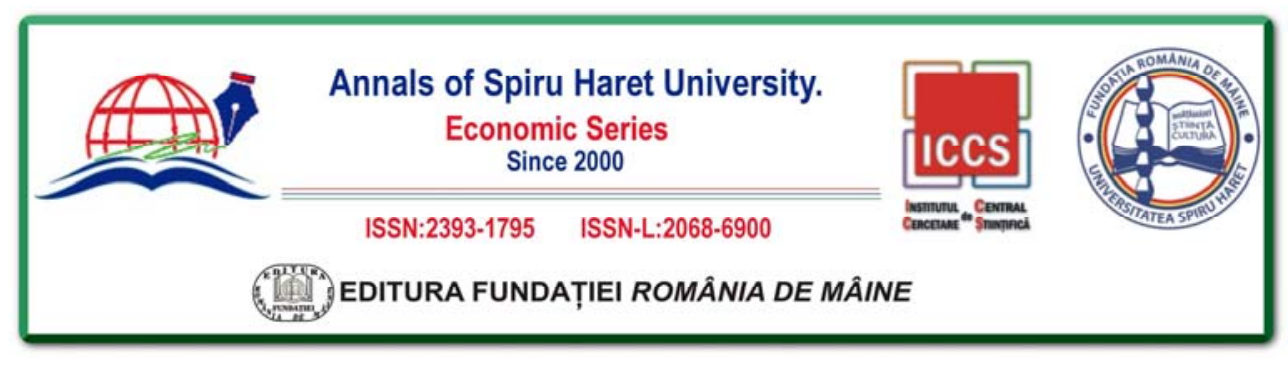

Issue $2 / 2018$

\section{Review of related literature}

\subsection{Conceptual framework}

Personal reputation is linked to other equivalent concepts such as the image, the prestige, the status, the reputation, the personal best, the celebrity, the legitimacy or the credibility. Researches converge in defining the personal reputation according to common parameters which allow to be defined as "the consideration which is given to a person based in a number of perceptions built over the course of time result of the - direct or indirect (through third parties) - observation of the image it projects, of its personal characteristics, of its achievements and of the history of its behaviour in different environments” [Jácome López, 2015].

In terms of corporate reputation, the origins of the concept, as we know it at present, date back to 1958 as a result of a study from Pierre Martineau in which he already indicated the advantages of expanding the notion of brand image to corporate image, as well as pointing its complexity and diversity. Decades after this study, the concept has little impact in scientific and business literature. It is from the 1980s when the term begins to gain in importance through the publishing of the first rankings of the most admired companies in North America in Fortune magazine [Carreras et al, 2013]. It is a survey of 10,000 executives and financial analysts in order to evaluate the most important 500 companies depending on eight criteria linked to reputation (management quality, products or services, innovation, financial soundness, prudent use of the corporate assets, long-term investment, ability to attract talented people and social and environmental responsibility). From that point, the number of publications related to corporate reputation has been increasing.

Between 1958 and 1988 there is a shortage of scientific production in the area of corporate reputation. For Carreras, Alloza \& Carreras [2013], "the origin of disinterest lies in the fact that reputation research is mainly associated with advertising. From the 1990s onwards, reputation is associated with market value and is no longer tied to advertising and selling. This ability to create value is what makes it a focus of research in itself".

Therefore, you go from a research program where reputation is related to advertising and where the focus is the credibility of the message (and where reputation plays a subsidiary role) to a program where reputation is related to value and plays a central role. This paradigm shift attached to the interest of the business world stimulated the production of studies about reputation and some authors even 


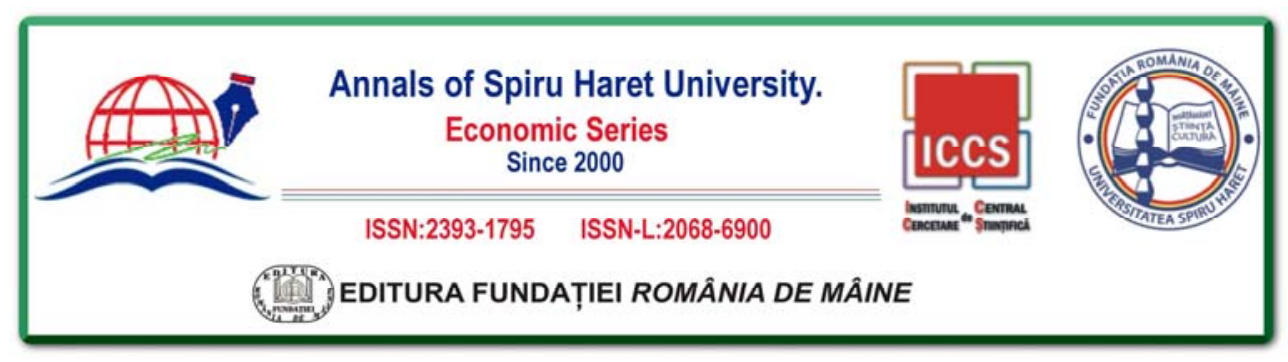

\section{Issue 2/2018}

spoken about 'Tower of Babel' [Hatch \& Schultz, 2000] because of the variety of different approaches and concepts that are used.

With regard to the reputation in the virtual world, convergence between the rise of new technologies connected with corporate communication has favoured the birth of what has been called the online reputation [Mut, 2012].

Chun \& Davies [2001] make a first approximation in the academic world to the concept of online reputation and they speak about e-reputation "to refer to that element of reputation which is derived specifically from electronic contacts".

Siano, Vollero \& Palazzo [2011] explain the formation of the reputation on the Internet in three consecutive stages: design and training, refraction and evaluation. In the first stage, brands employ different strategies in order to reach their stakeholders, to transmit their values and to establish relations. The interactive possibilities of the Internet would make it easier for these groups to answer with opinions and comments about the company's performance and behaviour. Finally, interest groups combine the image projected by the brand with the opinion of other stakeholders. What distinguishes and makes unique this process in the field of the Internet is the time required for its development, which is much smaller in this context.

The amount of non-academic publications (blog posts, popular magazine articles or press articles) that talk about online reputation management and social media management is very large. In these cases, online reputation is linked to "SEO problems, social media optimization (SMO), crisis management, monitoring and personal reputation" [Vaquero, 2012]; in other words, "in many cases online reputation is based on reductionist concepts about search engines or sentiment analysis on social media” [Mut, 2012].

The use of the concept online reputation applied to company communications in the virtual environment has led it to "a real alteration of its meaning, to degradation by misuse of the term and to devirtualization of its theoretical load" [Mut, 2012]. For this author, "we should understand what is known as online reputation as something integral to corporate reputation and, consequently, it must be managed with the same indicators or disaggregated by it”.

This means that by focusing the online reputation management on actions with a strong technical nature, such as SEO, SEM, online monitoring, personal or blog views, social media, etc., we become lax on the own concept of reputation and its strategic importance for organizations [Mut, 2012]. 


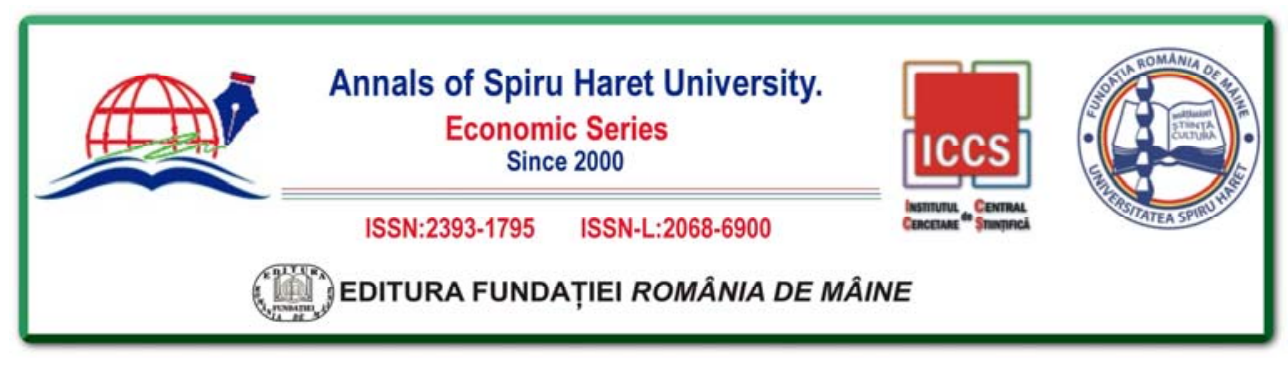

Issue $2 / 2018$

Although the literature which is about online reputation considers it from the prevention and elimination of reputational risks [Vaquero, 2012] and not all views and actions of users can be reputational threats [Carreras, 2008], it is true that when users decided to comment a service or product on their own initiative is generally when the consumer experience has not been positive [Noguera, 2006]. Dans [2011] points out that online reputation is not improved by deleting negative reviews around the Internet, but "improving the management and the reality of the organization (...) the quality of service, customer service or management policies".

To understand the reason for this situation we should look back to 1999 and to the influence of The Cluetrain Manifesto by Fredrick Levine, Christopher Locke, Doc Searls and David Weinberger. That document proposed 95 ideas for understanding the role of business and customers in the new technological environment (the Internet). This document rose "the urgent need for companies to take advantage of the Internet to establish an agile (adaptable) and fast-moving (networked) contact to respond to customer needs" [Noguera, 2006].

If, as it is said in The Cluetrain Manifesto, “'markets are conversations', users and companies must make an effort to understand conversation rules which take place in the Internet because both the Internet and social media have managed to democratize participation and companies no longer have absolute control over communication" [Aced, 2013]. For Orihuela [2011] "the individual has an outstanding ability to adapt to technological change (...). And corporations have had to evolve simultaneously to understand the new codes of digital age”.

As a consequence, the Internet user takes "a sceptical attitude, distrustful. The tendency to think about intrusion, selling, deception (...). The improvement of its skills to judge proposals is an indisputable fact (...). The use of new technologies and Internet has provided the user with tools that allow them to obtain a direct contact with the companies" [Gil \& Romero, 2008].

In fact, the word-of-mouth takes a critical dimension on the Internet and has distributed the power of reputation building, which no longer is a monopoly of the organization itself, but it is configured from messages that anyone can launch [Leiva-Aguilera, 2012].

The organization reputation is permanently exposed on the Net, hence the need for organizations to be complete and integral. Thereby, the Net requires to be transparent because, to the slightest trace of deception, the virtual view that moves in cyberspace leaves it without impact on the market. A scandal is quickly feedback 


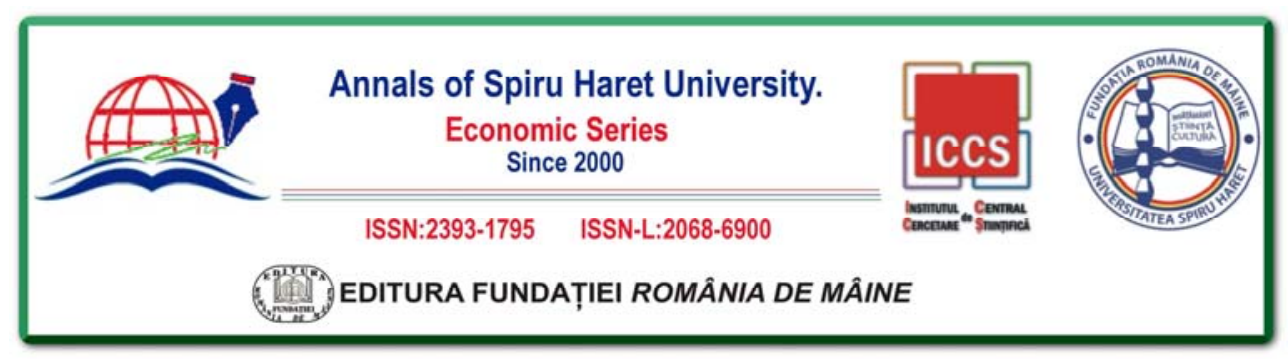

\section{Issue $2 / 2018$}

by other historical on the Net because in it are all the vestiges and you can find the historical referents [Leiva-Aguilera, 2012].

New technologies have generated new behaviours that are establishing new social forms [Schwartz, 2009]. Traditional patterns of communication have been adapted to a new context which is influenced by trends that mark social media [Atarama \& Cortéz, 2015]. In fact, Fombrun [2011] talks about "a new 'reputation economy' where society would be highly connected through networking and organizations that would operate in an ecosystem of permanent influence from stakeholders. In this analytical scheme, since that information would not be systematically distributed among networks, trust and relations would become vital events”.

Collaborative consumption and the sharing economy have become social and economic phenomenon in just a few short years [De Rivera et al, 2016; Hofmann et al, 2017; Key, 2017; Möhlmann, 2015; Pera et al, 2016; Xie \& Mao, 2017]. Collaborative consumption websites have enabled consumers to focus on shared access to products rather than owning them [Barnes \& Mattsson, 2017]. In many sharing economy marketplaces, members rely entirely on interpersonal trust as a form of currency [Parigi et al, 2017]. While in conventional business relations, consumers are protected from undesirable customer behaviour by laws, regulations (power) in the context of collaborative consumption are rare, so that trust becomes more relevant [Hofmann et al, 2017] like online reviews can have a direct effect on the online sales of a company [Lian et al, 2017].

Trust is, therefore, a key factor in overcoming uncertainty and mitigating risk [ter Huurne et al, 2017]. In this way, perceived trust has positive effects on tourists' behavioural intentions [Wu et al, 2017]. Also, trust has been widely recognized as the crucial factor of consumer purchase intention when shopping on peer-to-peer short-term rental platforms where hosts and renters are strangers [Weber, 2014; Wu et al, 2017]. And mutual trust between trading partners is important [Seo et al, 2017]. The premise of reputation systems is that the aggregate rating associated with a person is an indicator of the quality and the risk entailed in potential transactions with that individual [Abrahao et al, 2017].

It would be a "new economic paradigm characterized by the growing influence and decision-making power of costumers" [Sampol et al, 2015], where "individual reputation can be added and is beginning to be considered as a form of capital in itself” [Mazzella \& Sundararajan, 2016]. It is in this context where are emerging 


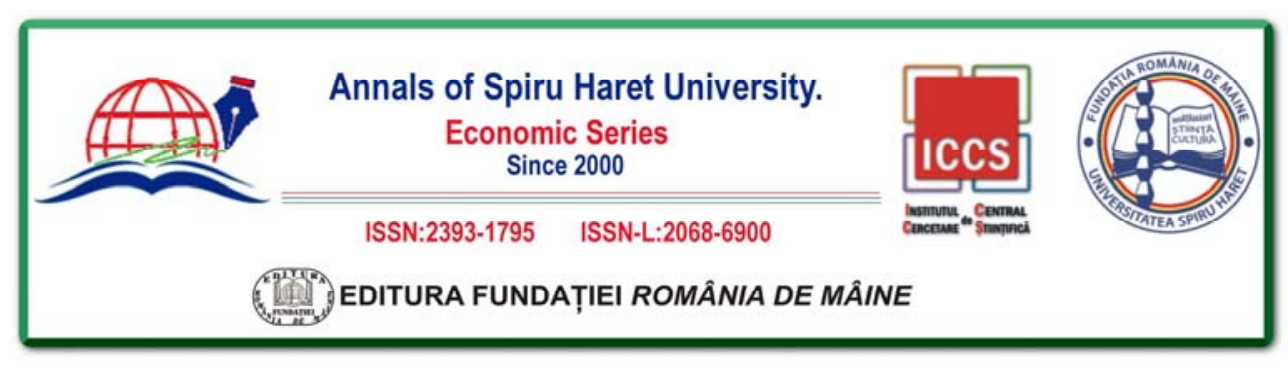

Issue $2 / 2018$

initiatives such as Traity that offer their users a reputation passport that allows them to prove their prestige to anyone.

\section{Methodology}

The bulk of the investigation is from a strong qualitative nature and for this purpose we have opted for the case study method, combining data from several sources: collection and assimilation of bibliographic material and literature related to research framework, analysis of the contents displayed on the startup websites under investigation (blog, website, official Twitter account) and interviews with Juan Cartagena (@JC2go), founder of the company.

Therefore, our study is based on a qualitative research focused on a case study, with an exploratory purpose, since we intend to "achieve a rapprochement between the theories inscribed in the theoretical framework and the reality under consideration” [Martínez Carazo, 2006]. Many authors have developed theories about the existence of an ideal number of cases to study [Martínez Carazo, 2006]. Finally, they come to the conclusion that there are no rules for specifying the sample size, leaving this decision to the researcher and the size of theoretical saturation reached in the research. In our study, we will opt for the study of a single case, since Traity brings together a number of characteristics (objective of creating a standard online reputation based in scale of personal reliability by adding information available online and verified offline, technical development in open source, blockchain, open and transparent innovation) that make it a pioneer.

\section{Case study: Traity}

Continuously, we meet strangers on the Internet. We meet, share our house, office, car, tools with them... but, unfortunately, there is always a fear to deal with them and they feel the same way.

Traity emerges as a network of trusted people. Its mission as a company is to create a world where "everyone can trust each other". It is a startup that has developed an online reputation system based in digital fingerprint. Its vision is to create a more inclusive world where offline reputation can be accredited to provide opportunities that would otherwise be denied. It was created on 2012 and its founders were Juan Cartagena, Telecommunications Engineer from the Universidad Politécnica de Madrid and MBA in the Chicago Booth; Borja Martín Sánchez de 


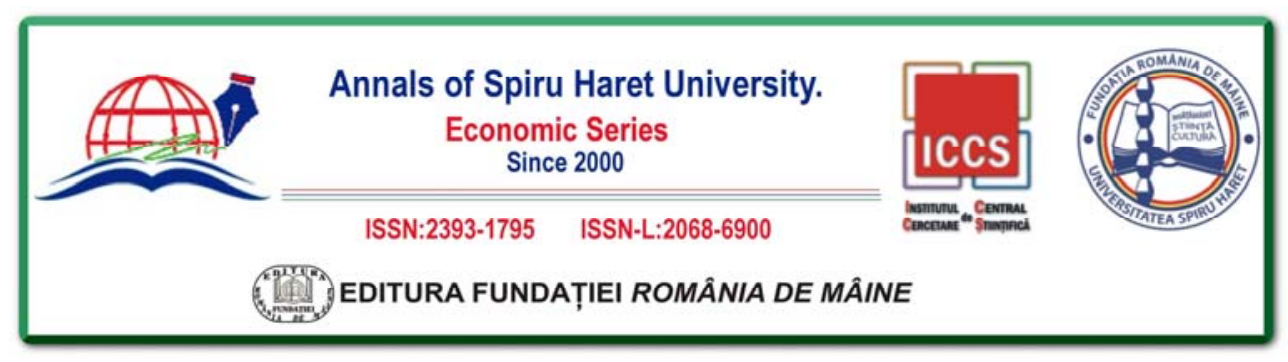

\section{Issue 2/2018}

Vivar, Technical Engineer in Computer Systems from the Universidad Europea, and José Ignacio Fernández, $\mathrm{PhD}$ in Telecommunications Engineering from the Universidad Politécnica de Madrid. At present, all three continue in the company: Juan is the CEO (Chief Executive Officer), Borja Martín is the CDO (Chief Digital Officer) and José Ignacio is the CTO (Chief Technology Officer) of the company.

Traity raises a reputational punctuation that harnesses the digital fingerprint information to reproduce the online trust just the way we understand it in the physical world, but without trying to reduce people to a number or stars as we were in chapter 'Nosedive' from TV Netflix show Black Mirror. Traity profile goes far beyond this dystopia because it allows users a deeper interaction as it is an open, accessible and transparent profile in public data.

In Traity, they believe that there are three basic concepts in its definition of reputation:

1. It is a dynamic property you win or lose depending on the behaviour results when interacting with others.

2. Reputation is not a currency (you do not spend it when using it, rather you endanger it, and does not have a limited quota).

3. Reputation is an active that we would enable to get access to inaccessible services without that credential (property, credit, etc.).

\subsection{Calculation of reputation}

As appears from the frequently asked questions on its website, the process has 5 stages:

1. The first stage is identity phase. They make sure that the person is who they say they are. They ask users to log in with different social media, whose reliability they check and they review if the name is consistent through them, or if the person has the same friends in the various networks. There is also an offline verification (to load the passport or identity card to verify it). After deleting the photo, they maintain the fact that the person has been verified with their real name. This stage is one of the biggest obstacles to reputation economy and it is precisely a matter of transparency.

2. The second stage is about biography, personality and achievements. The more the person tells about themselves, the more transparent they are and they will become clearer before the others. This does not 'prove' that their reputation is high 


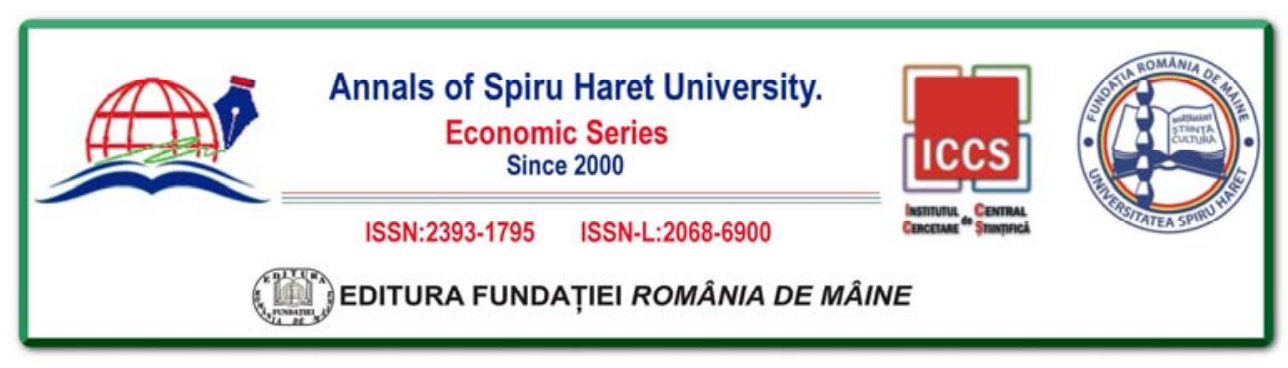

Issue $2 / 2018$

because everyone can write good things about ourselves, but it is part of that subjective reputation whereby we trust people similar to ourselves. It is not about good or bad but rather it is about who/how that person is.

3. The next stage is about social media study: who are their best friends, where they spend most of their times, if it is consistent where their friends spend their time. In conclusion, they try to make the process of distorting social identities harder.

4. The fourth stage is about recommendations. This is part of the reputation and these are actions that happen within Traity through a ranking represented with medals (gold, silver, bronze, seed). Medals would be a synthetic way of interpreting reputation that Traity considers more useful than rates, scales or stars.

5. Traity is being integrated into different reputable websites, such as collaborative consumption platforms and sharing economy. All these platforms have their own reputation system, which can be inefficient because users have to start from scratch on each platform. And if all of them have passport verification, they have to upload their passport to 100 different sites. The API of reputation is the basis of the entire infrastructure of Traity. Economy reputation companies could include and draw information (with the user's approval) to introduce more reputation inside the system and integrate it with their own reputation profiles.

\subsection{Privacy}

In Traity, data are encrypted and are not shared with third parties. They use blockchain as log book (fingerprint). It is a safe and immutable environment that "many links only to the arrival of cryptocurrencies and the media hype starred by bitcoin, but which is an ideal solution for any transactional event, and that we will see everywhere, to the point of forming the world's largest supercomputer and to the point of being able to create a new Internet” [Dans, 2017].

Blockchain is a database that registers property, transactions and any type of information. It is a distributed, unchanged and public net that although it is associated to the popular imaginary to the deep web and to illegal activities, among its advantages it allows the traceability of information chains and transactions, increasing the neutrality of the Net and facilitating the detention of fraud. As it is a decentralized network, it is less vulnerable to an attack that puts at risk user's sensitive data. 


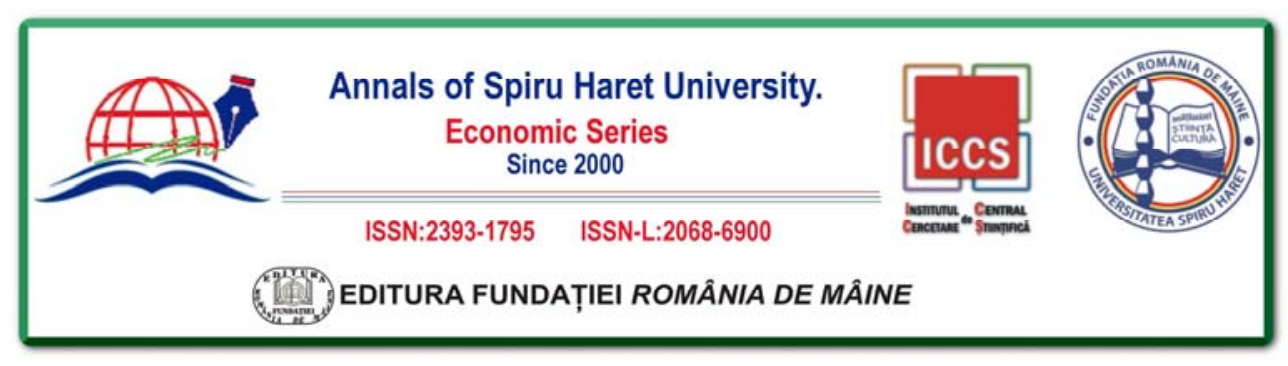

\section{Issue $2 / 2018$}

In Traity, they assure not to provide data to third parties nor try to monetize them (as some social tools do) nor implement intrusive practices as unsolicited notifications. Traity focus is to help users to use their data in order to improve their lives and, in such a manner, they hope to make money in the future. A social media will use users' data to try to make money: if you do not pay for the product, then you are the product. If we look at its assertions, this would not be Traity's case.

Table no. 1. Traity's data

\begin{tabular}{|l|l|}
\hline Creation & July 2012 \\
\hline Web & www.traity.com \\
\hline Products & $\begin{array}{l}\text { Trustbond (active) } \\
\text { Kevinsurance (active) } \\
\text { REY (stealth mode) }\end{array}$ \\
\hline Finances & 2014 \$4,7M (Active Venture Partners) \\
\hline Users registered & More than 4,500,000 \\
\hline Prizes & $\begin{array}{l}\cdot \text { EmprendedorXXI Madrid 2013 } \\
\text { BBVA OpenTalent 2013 } \\
\cdot \text { Spain Startup 2013 } \\
\cdot \text { Bizcamp Tel Aviv 2012 } \\
\cdot \text { Seedcamp Berlin 2012 } \\
\text { 2nd place ActuaUPM 2012 }\end{array}$ \\
\hline Competence & $\begin{array}{l}\text { TrustCloud by Branddocs } \\
\text { miiCard }\end{array}$ \\
\hline
\end{tabular}

Source: Own elaboration.

\subsection{Operating examples}

Syters (Syters Cuidados, S.L.) raises a website that puts babysitters and nurses in touch with parents or people in need of care. All babysitters and nurses have a 


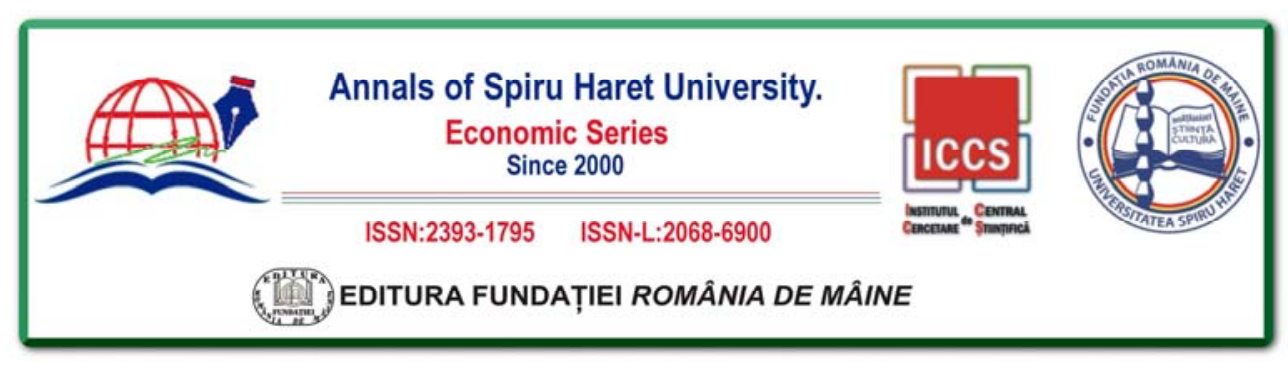

Issue $2 / 2018$

profile in Traity where other parents, future customers, can see their professionalism and skills, something that will be reflected by the scores they get. A similar process can occur with other companies, such as Joyners which are dedicated to the care for the elderly.

DAS España (Grupo ERGO) offers legal protection to individuals, companies and other insurance companies. Their customers have access to a provision of legal services by specialist lawyers and collaborators located throughout Spanish territory. Its alliance with Traity is to offer a new rental insurance based in online reputation. The product will facilitate the access to housing by using the social reputation of the tenant introducing social reputation (social scoring) as an alternative to traditional methods of financial analysis. The service will allow tenants to guarantee their payment capacity with their reputation in social media and in collaborative consumer websites.

\section{Conclusions}

After the case study, the first of the drawbacks detected is that it is a complex technology and should not be shown to the public with this complexity. Although to register is an easy process, Internet users could have difficulties to understand why they have to provide Traity access to all their personal data and social media accounts, electronic trading and sharing economy platforms: name, surname, telephone number, e-mail address, identity card/passport, Facebook, Twitter, Coinbase, PayPal, Amazon, eBay, etc.

Secondly, the ranking represented by medals (gold, silver, bronze or seed) is a visually very acceptable solution and it would be a synthetic way of interpreting the reputation that Traity considers more useful than percentages, scales or stars, but they do not explain why that ranking is better than the mentioned above.

Thirdly, another of the issues that draws the attention of researchers is the assertion that is made from Traity by ensuring that they will not give their data to third parties nor try to monetize them; it would take more than the word of the founders to support this fact, especially in a business model based on trust.

In relation to the contributions of this model, the main one that emerges from the statements and analysis of its website is to ensure that users who do not have financial identity but do have social identity, online and offline, can access insurance, credits, employment and other opportunities, aid of their reputation.

Another possible contribution refers to one of the main questions on the sharing economy platforms, on social media and on other websites of recommendations: 


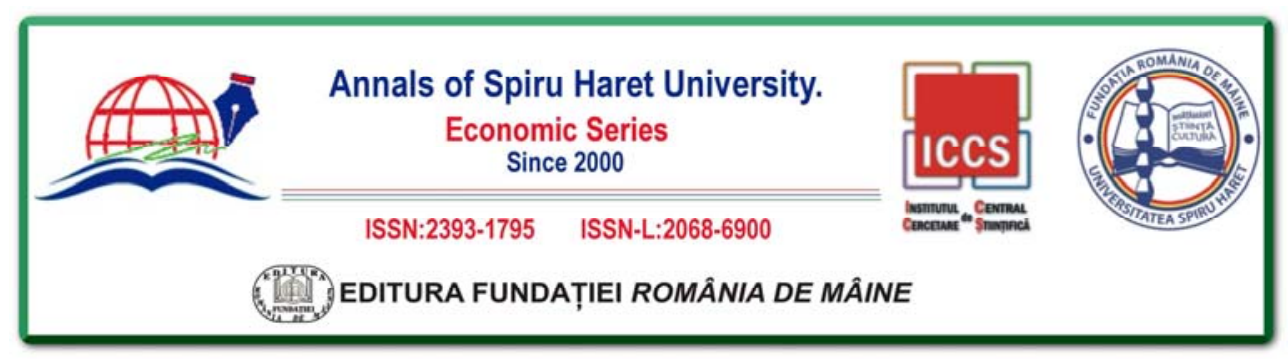

\section{Issue $2 / 2018$}

who owns the user's reputation, themselves or the platform. The most relevant websites (Airbnb, Blablacar, Uber, Homeaway...) speak out for reserving the right to the published contents or comments and assessments that are part of their reputation systems. In this regard, a service like Traity would offer the possibility of using, anywhere, the different reputations we have.

With reference to project's viability, this is not the subject of the investigation. Nevertheless, it should be noted that Traity, after an investment of more than $\$ 4,5$ million in 2014, at present is looking for business models related to InsurTech, risk scoring or financial services. Having said that, we have seen that almost all projects related to the industry reputation as Karma, Briiefly, RepStamp Trustribe, Peertrust, Project Trust, Truly, Credport, Fidbacks or Virtrue have closed their doors. Only miiCard and TrustCloud by Branddocs are still active.

Furthermore, the commercial operation of this business model, after closing the door to the transfer of data to third parties, would be limited to several options: charge users for their services or commercially exploit advertising space on their website through affiliate marketing or others finance ways like crowdfunding or Initial Coin Offers.

In the coming months or years, we will check whether the project remains active.

\section{References}

1. Abrahao, Bruno, Parigi, Paolo, Gupta, Alok, and Cook, Karen S. "Reputation Offsets Trust Judgments Based on Social Biases among Airbnb Users", Proceedings of the National Academy of Sciences, 114 (2017): 9848-9853, accessed March 18, DOI: https://doi.org/10.1073/pnas.1604234114

2. Aced, Cristina. Relaciones Públicas 2.0. Cómo gestionar la comunicación corporativa en el entorno digital (Barcelona: Editorial UOC, 2013).

3. Atarama Rojas, Tomás, and Cortés Alburqueque, César. "La gestión de la reputación digital en las universidades. Twitter como herramienta de la comunicación reputacional en las universidades peruanas," Revista de Comunicación 14 (2015): 26-47, accessed May 28, 2018, http://revistadecomunicacion.com/pdf/2015/Art026-047.pdf

4. Barnes, Stuart J., and Mattsson, Jan. "Understanding collaborative consumption: Test of a theoretical model”, Technological Forecasting and Social Change 118 (2017): 281292, DOI: https://doi.org/10.1016/j.techfore.2017.02.029 


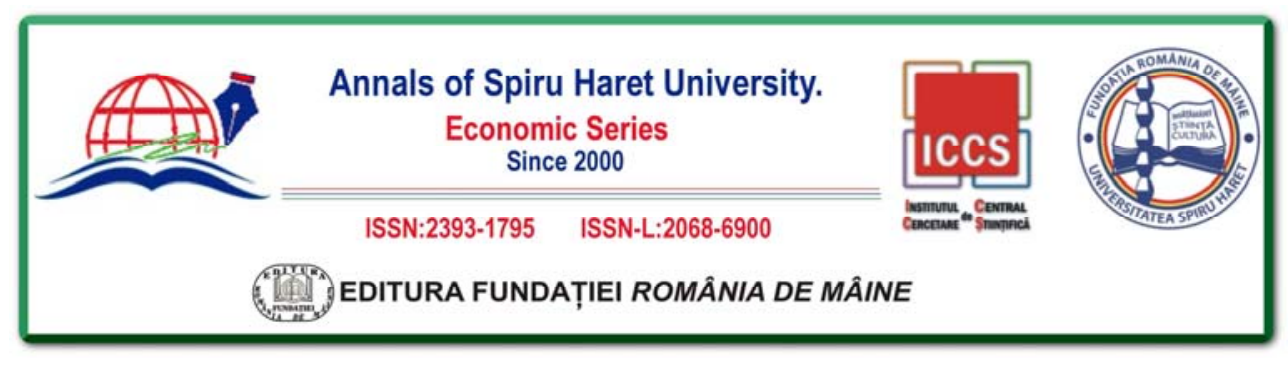

Issue $2 / 2018$

5. Capriotti, Paul. "De la imagen a la reputación: análisis de similitudes y diferencias," Razón y Palabra, 70 (2009): 1-10, accessed May 14, 2018, http://www.razonypalabra. org.mx/Articulo\%2013\%20CAPRIOTTI\%20Imagen\%20y\%20ReputacionR\&P.pdf

6. Carreras, Enrique, Alloza, Ángel, and Carreras, Ana. Reputación Corporativa (Madrid: LID Editorial Empresarial, 2013).

7. Carreras, Roberto. "Lo que no es y podría ser la Reputación Online”, accessed May 19, 2018, https://materialesmarketing.wordpress.com/2010/11/19/lo-que-no-es-y-podriaser-la-reputacion-online/

8. Cartagena, Juan. “About our Venture Round,” Traity Blog, accessed May 19, 2018, https://blog.traity.com/about-our-venture-round-2e3666285c22

9. Cartagena, Juan. " 6 challenges of the future of reputation and trust," Traity Blog, accessed May 19, 2018, https://blog.traity.com/6-challenges-of-the-future-of-reputationand-trust-d968602a31fd

10. Chun, Rosa, and Davies, Gary. "E-reputation: the role of mission and vision statements in positioning strategy," Journal of Brand Management, 8 (2001, Spring): 315-333.

11. Dans, Enrique. "Seguimiento y evaluación: mitos y leyendas online en la nueva era digital 2.0", Corporate Excellence - Centre for Reputation Leadership (2011), accessed May 15, 2018,: http://www.corporateexcellence.org/index.php/content/download/2502/ 26097/file/T05\%202011\%20Del\%20seguimiento\%20a\%20la\%20evaluaci\%C3\%B3n\% 20de\%20la\%20reputaci\%C3\%B3n.pdf

12. Dans, Enrique. Introduction to La revolución blockchain: Descubre cómo esta nueva tecnología transformará la economía global, by Don Tapscott \& Alex Tapscott (Barcelona, Ediciones DEUSTO, 2017), accessed May 15, 2018, https://www.enriquedans.com/2017/02/prologo-de-la-revolucion-blockchain-de-don-yalex-tapscott.html

13. De Rivera, Javier, Gordo, Ángel, Cassidy, Paul, and Apesteguía, Amaya. "A netnographic study of P2P collaborative consumption platforms' user interface and design”, Environmental Innovation and Societal Transitions 23 (2017): 11-27, DOI: https://doi.org/10.1016/j.eist.2016.09.003

14. Ert, Eyal, Fleischer, Aliza, and Magen, Nathan. "Trust and reputation in the sharing economy: The role of personal photos in Airbnb”, Tourism Management 55 (2016): 6273, DOI: https://doi.org/10.1016/j.tourman.2016.01.013

15. Fombrun, Charles. "Reputations, roller coasters and wild rides on wall street" (Cartel sesión presented at Primera Conferencia Latinoamericana de Reputación Corporativa. Cartagena, Colombia, October 13-14, 2011).

16. Gil, Víctor, and Romero, Felipe. Crossumer. Claves para entender al consumidor español de la nueva generación (Madrid: Gestión 2000, 2008). 


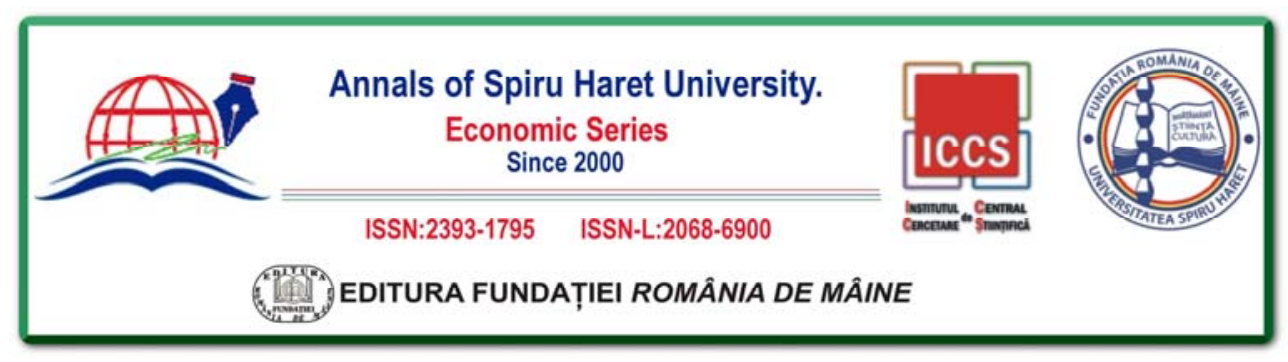

\section{Issue $2 / 2018$}

17. Hofmann, Eva, Hartl, Barbara, and Penz, Elfriede. "Power versus trust-what matters more in collaborative consumption?”, Journal of Services Marketing 31.6 (2017): 589603, DOI: https://doi.org/10.1108/JSM-09-2015-0279

18. Hosmer, Larue Tone. "Trust: the connecting link between organizational theory and philosophical ethics," Academy of Management Review, 20 (1995, 2): 379-403.

19. Huurne, Maarten ter, Ronteltap, Amber, Corten, Rense, and Buskens, Vincent. "Antecedents of trust in the sharing economy: A systematic review", Journal of Consumer Behaviour 16.6 (2017): 485-498, DOI: https://doi.org/10.1002/cb.1667

20. Itoiz López, Maite. “En la era digital, ¿reputación o reputación online?” in El nuevo diálogo social: organizaciones, públicos y ciudadanos, Several Authors (Valencia: Campgrafic, 2015), 137-148.

21. Jácome López, Rita. "La impression management aplicada a la construcción de reputación personal y en las organizaciones: el caso del DirCom” (PhD diss., Universitat Politècnica de València, 2015). doi:10.4995/Thesis/10251/59524

22. Leiva-Aguilera, Javier. Gestión de la reputación online (Barcelona: Ed. UOC, 2012).

23. Liang, Sai, Schuckert, Markus, Law, Rob, and Chen, Chih-Chien. "Be a "Superhost": The importance of badge systems for peer-to-peer rental accommodations", Tourism Management 60 (2017): 454-465, DOI: https://doi.org/10.1016/j.tourman._2017.01.007

24. Martin Key, Thomas. "Domains of Digital Marketing Channels in the Sharing Economy", Journal of Marketing Channels 24.1-2 (2017): 27-38, DOI: https://doi.org/10.1080/1046669X.2017.1346977

25. Martínez Carazo, Piedad Cristina. "El método de estudio de caso: estrategia metodológica de la investigación científica,” Pensamiento \& Gestión, 20 (2006): 165193, accessed April 20, 2018, http://www.redalyc.org/pdf/646/64602005.pdf

26. Mazzela, Frédéric, and Sundararajan, Arun. Entering the Trust Age (France, 2016), accessed March 28, 2018, https://www.blablacar.com/wp-content/uploads/2016/ 05/entering-the-trust-age.pdf

27. Möhlmann, Mareike. "Collaborative consumption: determinants of satisfaction and the likelihood of using a sharing economy option again", Journal of Consumer Behaviour 14.3 (2015): 193-207, DOI: https://doi.org/10.1002/cb.1512

28. Mut Camacho, Magdalena. "La desvirtualización del concepto reputación en el entorno virtual," adComunica. Revista Científica de Estrategias, Tendencias e Innovación en Comunicación, 3 (2012): 227-229, accessed May 1, 2018, DOI: http://dx.doi.org/10.6035/2174-0992.2012.3.18

29. Noguera, José Manuel. "La bitácora como producto ciberperiodístico y corporativo de los medios de comunicación: aproximación a las relaciones de los cibermedios con la comunidad bloguer” (PhD diss., Universidad Católica de Murcia, 2006). 


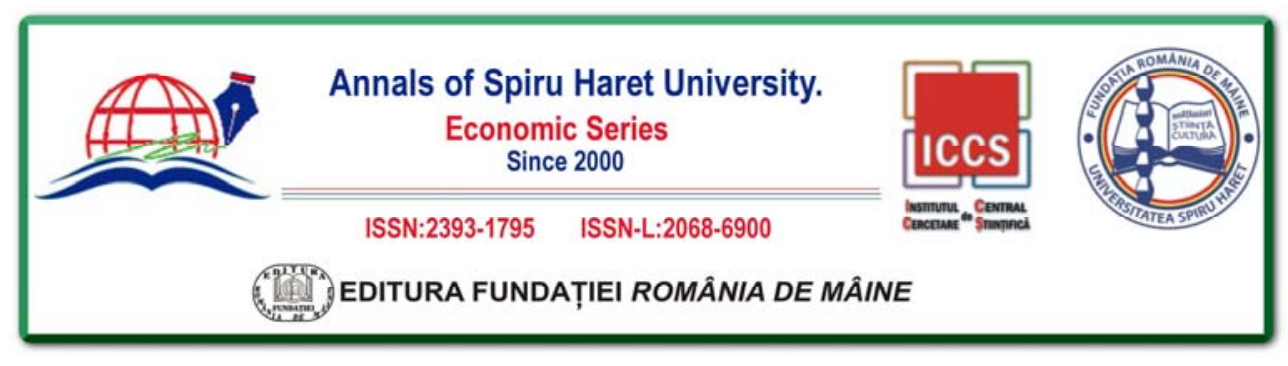

Issue $2 / 2018$

30. Orihuela, José Luis. Mundo Twitter: Una guía para comprender y dominar la plataforma que cambió la red (Barcelona: Atlanta, 2011).

31. Parigi, Paolo, Santana, Jessica J., and Cook, Karen S. "Online field experiments: studying social interactions in context”, Social Psychology Quarterly 80.1 (2017): 1-19, DOI: https://doi.org/10.1177/0190272516680842

32. Pera, Rebecca, Viglia, Giampaolo, and Furlan, Roberto. "Who am I? How compelling self-storytelling builds digital personal reputation”, Journal of Interactive Marketing 35 (2016): 44-55, DOI: https://doi.org/10.1016/j.intmar.2015.11.002

33. Pérez Sampol, Cristina, Gómez-Zorilla Amate, José María, and Jorge Marco Blanco. "La comunicación empresarial en la Web 2.0. Estrategias para la gestión efectiva de la reputación corporative,” Revista Tecnología, Ciencia y Educación, 1 (2015): 62-67.

34. Pizzolante, Italo. “La 'Geometría’ de la Comunicación Empresarial,” Razón y palabra, 34 (2003), accessed March 28, 2018, http://www.razonypalabra.org.mx/anteriores/ n34/ipizzolante.html

35. Schwartz, David G. "Toward the next generation of social networking applications", Internet Research, 19 (2009, 3), DOI: https://doi.org/10.1108/intr.2009.17219caa.001

36. Seo, Aria, Jeong, Junho, and Kim, Yeichang. "Cyber Physical Systems for User Reliability Measurements in a Sharing Economy Environment”, Sensors 17.8 (2017): 1868, DOI: 10.3390/s17081868

37. Siano, Alfonso, Vollero, Agostino, and Palazzo, María, "Exploring the Role of Online Consumer Empowerment in Reputation Building: Research Questions and Hypotheses", Journal of Brand Management, 19 (2011, 1): 57-71, DOI: https://doi.org/ 10.1057/bm.2011.23

38. Vaquero Collado, Alicia. “La reputación online en el marco de la comunicación corporativa. Una visión sobre la investigación de tendencias y perspectivas profesionales”, adComunica, 3 (2012): 49-63, DOI: http://dx.doi.org/10.6035/21740992.2012.3.4

39. Weber, Thomas A. "Intermediation in a sharing economy: insurance, moral hazard, and rent extraction”, Journal of Management Information Systems 31.3 (2014): 35-71.

40. Wu, Jiang, Ma, Panhao, and Xie, Karen. "In sharing economy we trust: the effects of host attributes on short-term rental purchases”, International Journal of Contemporary Hospitality Management 29.11 (2017): 2962-2976, DOI: https://doi.org/10.1108/ IJCHM-08-2016-0480

41. Wu, Jiang, Zeng, Minne, and Xie, Karen. “Chinese travelers' behavioral intentions toward room-sharing platforms: The influence of motivations, perceived trust, and past experience", International Journal of Contemporary Hospitality Management 29.10 (2017): 2688-2707, DOI: https://doi.org/10.1108/IJCHM-08-2016-0481 


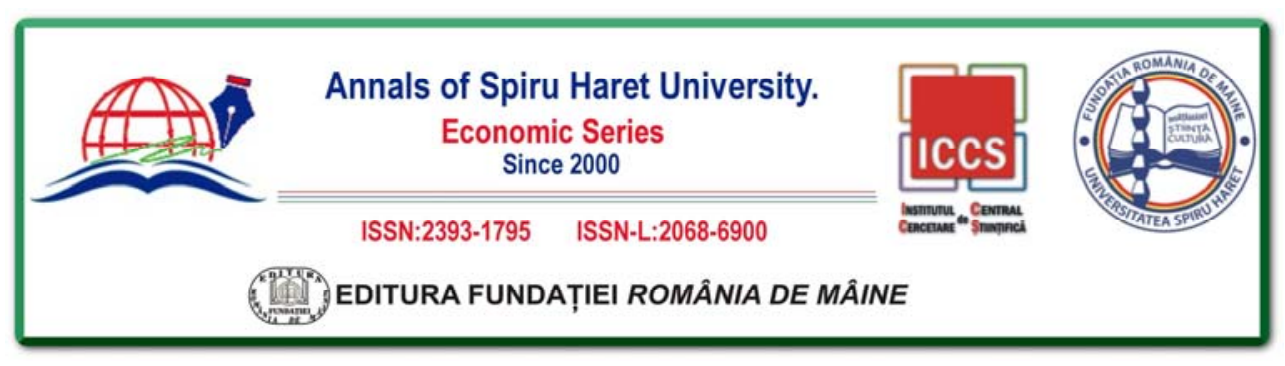

\section{Issue $2 / 2018$}

42. Xie, Karen, and Mao, Zhenxing. "The impacts of quality and quantity attributes of Airbnb hosts on listing performance", International Journal of Contemporary Hospitality Management 29.9 (2017): 2240-2260, DOI: https://doi.org/10.1108/ IJCHM-07-2016-0345 
DOCTORAL AND POSTDOCTORAL PAPERS 
